\title{
Quantitative Studies of the Avidity of Naturally Occurring Substances for Trace Metals
}

\author{
3. PTERIDINES, RIBOFLAVIN AND PURINES
}

\author{
By A. ALBERT \\ Department of Medical Chemistry, The Australian National University*
}

(Received 29 November 1952)

8-Hydroxyquinoline (I) owes its well known avidity for metallic cations to the presence of an ionizable hydroxyl group peri to a tertiary heterocyclic nitrogen atom. The presence of a similar configuration in several of the naturally occurring purines, e.g. guanine (IV), riboflavin (III), and all but one of the naturally occurring pteridines, which are deriva. tives of (II), gave rise to a suggestion that these substances, also, bind metallic cations (Albert, $1950 b, c$ ).
Gibson \& Rubbo, 1953). A derivative of 8-hydroxyquinoline (xanthurenic acid) has been found in pathological urine (Musajo, 1935).

\section{METHODS}

All determinations were carried out at $20^{\circ}$. The source of metallio ions was as given in Part 1 (Albert, 1950a); the source of each metal-binding substance is given in Table 1, together with its ionization constants (the tolerances are<smiles>Oc1cccc2cccnc12</smiles>

(I)<smiles>Oc1ncnc2nccnc12</smiles>

(II)

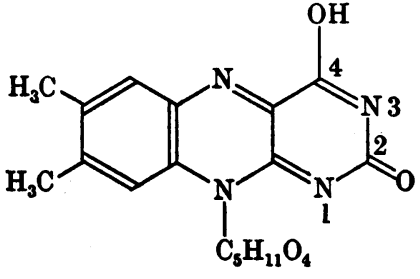

(III)<smiles>Nc1nc(O)c2nc[nH]c2n1</smiles>

(IV)<smiles>[O-]c1cccc2cccnc12</smiles>

(V)
In the present work the metal-binding properties of these substances have been demonstrated and measured. As a preliminary step, quantitative investigation of the avidity of 8-hydroxyquinoline (I) and its sulphonic acid was undertaken, both because these substances bridge a gap in behaviour that separates the substances to be studied from the amino-acids described in Parts 1 and 2 (Albert, $1950 a ; 1952)$, and because the stability constants of 8-hydroxyquinoline were required to interpret the antibacterial action of this substance which is under investigation (Albert, Rubbo, Goldacre \& Balfour, 1947; Rubbo, Albert \& Gibson, 1950; Albert,

* Present address: 183 Euston Road, London, N.W. 1. inserted wherever the determination was made specially for the present work). The metal-binding substances used were all chemically pure. Purity was confirmed: $(a)$ by the same constant being obtained from all parts of the potentiometric titration curve (in the absence of metals); (b) by melting point or by chromatography in three separate solvents when the substance had no melting point; $(c)$ by ultimate analysis (nos. 2-12 inclusive and 14).

The titrations were carried out as described in Part 1. One equivalent of $0.1 \mathrm{~N}-\mathrm{KOH}$ was used except for nos. 2, 5, 6 (which required two equivalents) and 10 (which required three). When metallic ions were present, the titrations were carried out at the concentrations shown in Table 1, except when the precipitation of complexes made a lower concentration necessary. In no case was a concentration lower than $0.001 \mathrm{~m}$ used. 


\section{Symbols}

$K_{a} \quad=$ Ionization constant.

$\mathrm{pK}_{a}=$ Negative logarithm of $K_{a}$.

$\left[\mathrm{M}^{2+}\right]=$ Concentration of free metallic ions.

[Sc] $=$ The concentration of the complex-forming species, e.g. (V) in the case of 8-hydroxyquinoline (I). It was calculated according to equations (vi) or (vii) of Part 2 (Albert, 1952) according to whether one or two equivalents, respectively, of alkali were used in the titration (see above).

$K^{\prime}$ (the first partial stability constant)

$$
=\frac{[\text { the } 1: 1 \text { complex, e.g. (VI)] }}{[\mathrm{Sc}]\left[\mathrm{M}^{2+}\right]} \text {. }
$$

$K^{\prime \prime}$ (the second partial stability constant)

$$
=\frac{[\text { the } 2: 1 \text { complex, e.g. (VII) }]}{[\mathrm{Sc}][\text { the } 1: 1 \text { complex }]} \text {. }
$$

$K_{8}$ (the overall stability constant, governing the complete reaction)

$$
=\frac{[\text { the 2:1 complex, e.g. (VII)] }}{[\mathrm{Sc}]^{2}\left[\mathrm{M}^{2+}\right]} \text {. }
$$

$\bar{n}=$ The average number of molecules of the substance combined with one atom of metal. Values of $\bar{n}$ were calculated according to equation ( $v$ ) of Part 2 (Albert, 1952).<smiles>[CH]1OC2=CC=CN3CC=CC1=C23</smiles>

(VI)

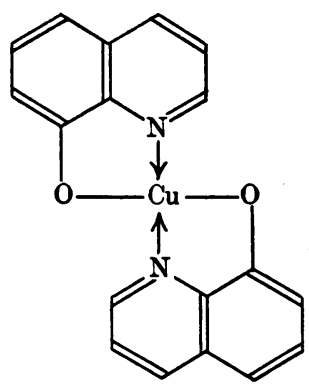

(VII)

\section{Calculations}

$\log K^{\prime}=\log \bar{n}-\log (1-\bar{n})-\log$ [Sc].

$\log K^{\prime \prime}=\log (\bar{n}-1)-\log (2-\bar{n})-\log [$ Sc].

$\log K_{s}=-2 \log$ [Sc], when $\bar{n}=1 \cdot 00$.

$\log K_{\mathrm{a}}=\log K^{\prime}+\log K^{\prime \prime}$.

$\log K_{s}=\log \bar{n}-\log (2-\bar{n})-2 \log [\mathrm{Sc}]$.

The choice of the correct equation, from the above, is discussed on pp. 647-8.

Derivation of equations. By definition, $\bar{n}=$ average number of molecules of substance combined with one atom of metal, hence

$$
\bar{n}=\frac{[\mathrm{VI}]+2[\mathrm{VII}]}{[\mathrm{VI}]+[\mathrm{VII}]+\left[\mathrm{M}^{2+}\right]},
$$

where [VI] and [VII] refer to the concentrations of the $1: 1$ and 1:2 complexes as exemplified by formulae (VI) and (VII) respectively. Then

$$
\frac{\bar{n}}{2-\bar{n}}=\frac{[\mathrm{VI}]+2[\mathrm{VII}]}{[\mathrm{VI}]+2\left[\mathrm{M}^{2+}\right]}
$$

When [VI] is small compared to $\left[\mathrm{M}^{2+}\right]$ and [VII], then

Hence from (a)

$$
\frac{\bar{n}}{2-\bar{n}}=\frac{[\mathrm{VII}]}{\left[\mathrm{M}^{2+}\right]} \text {. }
$$

$$
K_{8}=\frac{\bar{n}}{(2-\bar{n})[\mathrm{Sc}]^{2}}, \text { whence (v). }
$$

Derivations of equations (i) to (iv) have been given (Albert, $1950 a$ ).

\section{RESULTS}

The stability constants are reported in Table 2. These naturally occurring substances were found to form metal complexes less soluble, on the whole, than those of the simple amino-acids discussed in Part 1 (Albert, 1950a). Thus, in several cases it was impossible to obtain the second of the partial stability constants $\left(K^{\prime \prime}\right)$. Accordingly, closely related substances which might form more soluble complexes were sought. In this way, investigation of a more extensive portion of the titration curve in an anslogous substance could shed further light on the complex-forming properties of the natural substance.

Complex formation by the majority of the substances followed the same sequence as was found for the amino-acids (Albert, 1950a, 1952). First, one atom of the metal combined with one molecule of the substance. The $1: 1$ complex (e.g. VI) thus formed did not appreciably combine with a second molecule of the substance to give the $1: 2$ complex (e.g. VII) until at least $80 \%$ of the $1: 1$ complex had been formed (i.e. $\bar{n}=0 \cdot 8$ ). Normal addition, in this manner, can be diagnosed by the shape of the formation curve obtained when $\bar{n}$ is plotted against $-\log$ [Sc]. In Fig. 1, $C$ represents such a curve, theoretically derived,* and $A$ shows that it is parallel to a typical experimental curve (that of copper + glycine). This mechanism will be referred to as stepwise addition. In all such cases, both equations (i) and (ii) give consistent values (within $\pm 0 \cdot 2)$ for $\log K^{\prime}(\bar{n}=0 \cdot 1-0 \cdot 8)$ and $\log K^{\prime \prime}(\bar{n}=1 \cdot 2$ $1 \cdot 8)$ respectively.

A few of the substances listed in Table 1 showed quite a different pattern of addition to certain metals, particularly to copper. In these exceptional cases the shape of the formation curves (e.g. $B$ in Fig. 1) indicated that no appreciable quantity of the 1:1 complex accumulated, even in the first half of

* Derived by adopting any value for $K^{\prime}$ and working out values of $-\log [\mathrm{Sc}]$ for regular increments of $\bar{n}$, from equation (i). 
Table 1. Ionization constants $\left(20^{\circ}\right)$

(Sources: $A$, British Drug Houses Ltd. Recrystallized. B, Albert, Brown \& Cheeseman (1951). $C$, Albert \& Brown (1953). $D$, Albert \& Wood (1952). $E$, Albert, Brown \& Cheeseman (1952b). $F$, Brown (1953). $G$, Analytically pure grade, kindly presented by the American Cyanamid Company (Batch SR-9891). $H$, Special sample, free from aliphatic acids of low mol.wt., kindly presented by Roche Products Ltd., Welwyn Garden City. (Found: C, 54.2; H, 5.3; N, 15.0. Calc. for $\mathrm{C}_{17} \mathrm{H}_{20} \mathrm{O}_{6} \mathrm{~N}_{4}: \mathrm{C}, 54 \cdot 3 ; \mathrm{H}, 5 \cdot 4 ; \mathrm{N}, 14.9 \%$.) I, Nutritional Biochemicals Corporation, Ohio. Recrystallized. $J$, British Chemicals and Biologicals Ltd. Recrystallized. $K$, Levene \& Jacobs (1910).)

\begin{tabular}{|c|c|c|c|c|c|c|}
\hline No. & Substance & $\begin{array}{l}\text { Temp. } \\
\text { dried at } \\
\left({ }^{\circ}\right)\end{array}$ & Source & $\begin{array}{l}\text { Concen- } \\
\text { tration } \\
(\mathrm{M})\end{array}$ & $\mathrm{pK}_{a}$ (acidic) & $\mathrm{pK}_{a}$ (basic) \\
\hline 1 & 8-Hydroxyquinoline & 20 & $A$ & 0.005 & $9.89( \pm 0.03)$ & $5 \cdot 13( \pm 0 \cdot 02)$ \\
\hline 2 & $\begin{array}{l}\text { 8-Hydroxyquinoline-5-sulphonic acid } \\
\left(+2 \mathrm{H}_{2} \mathrm{O}\right) \\
\text { Pteridine }\end{array}$ & 20 & $A$ & 0.005 & $\left\{\begin{array}{l}1 \cdot 3^{*} \text { (approx.) } \\
8 \cdot 74( \pm 0 \cdot 02)\end{array}\right.$ & $4 \cdot 15( \pm 0.02)$ \\
\hline 3 & 4-Hydroxy- & 110 & $B$ & $0 \cdot 01$ & $7 \cdot 89$ & $<1 \cdot 3 \dagger$ \\
\hline 4 & 2:4-Dihydroxy- & 110 & $B$ & 0.01 & $\left\{\begin{array}{l}7 \cdot 92 \\
>12\end{array}\right.$ & $<1 \cdot 3$ \\
\hline 5 & 4:6-Dihydroxy- $\left(+1 \mathrm{H}_{2} \mathrm{O}\right)$ & 110 & $C$ & 0.0013 & $6.08 ; 9 \cdot 73 \ddagger$ & $<2$ \\
\hline $\begin{array}{l}6 \\
7\end{array}$ & $\begin{array}{l}\text { 4:7-Dihydroxy- } \\
\text { 2-Amino-4:6-dihydroxy- }\left(+1 \mathrm{H}_{2} \mathrm{O}\right) \\
\text { (xanthopterin) }\end{array}$ & $\begin{array}{l}110 \\
110\end{array}$ & $\begin{array}{l}C \\
D, E\end{array}$ & 0.001 & $\begin{array}{l}6 \cdot 08 ; 9 \cdot 62 \ddagger \\
6 \cdot 3 ; 9 \cdot 23 \ddagger\end{array}$ & $\underset{1.6}{<2}$ \\
\hline $\begin{array}{l}8 \\
9\end{array}$ & $\begin{array}{l}\text { 6-Anilinomethyl-4-hydroxy- } \\
\text { 6-Anilinomethyl-4-hydroxy- } p \text { - } \\
\text { sulphonate, sodium salt }\left(+2 \mathrm{H}_{2} \mathrm{O}\right)\end{array}$ & $\begin{array}{c}110 \\
20\end{array}$ & $\underset{F}{F}$ & $\begin{array}{l}0.001 \\
0.004\end{array}$ & $\begin{array}{l}7.92( \pm 0.02) \\
7.91 \ddagger( \pm 0.03)\end{array}$ & $\begin{array}{l}<3 \\
<2.5\end{array}$ \\
\hline $\begin{array}{l}10 \\
11 \\
12\end{array}$ & $\begin{array}{l}\text { Pteroylglutamic acid }\left(+2 \mathrm{H}_{\mathbf{2}} \mathrm{O}\right) \\
\text { Riboflavin } \\
\text { Inosine }\end{array}$ & $\begin{array}{r}20 \\
110 \\
20\end{array}$ & $\begin{array}{l}G \\
H \\
I\end{array}$ & $\begin{array}{l}0.002 \\
0.001 \\
0.01\end{array}$ & $\begin{array}{l}8.26 \neq, \S( \pm 0.06) \\
9 \cdot 93 \mid( \pm 0.05) \\
8 \cdot 82 \pi( \pm 0.01)\end{array}$ & $\|_{1 \cdot 5^{* *}}^{-}$ \\
\hline 13 & Hypoxanthine & 110 & $J$ & 0.005 & $\left\{\begin{array}{l}8.9490( \pm 0.02) \\
>11.5\end{array}\right.$ & $1 \cdot 98( \pm 0.02)$ \\
\hline 14 & Xanthosine $\left(+2 \mathrm{H}_{2} \mathrm{O}\right)$ & 20 & $K$ & 0.002 & $\left\{\begin{array}{l}5 \cdot 67 \dagger \dagger( \pm 0.02) \\
>11\end{array}\right.$ & $<2.5$ \\
\hline $\begin{array}{l}15 \\
16 \\
17 \\
18\end{array}$ & $\begin{array}{l}\text { Guanosine }\left(+\mathrm{lH}_{2} \mathrm{O}\right) \\
\text { Uric acid } \\
\text { Adenine } \\
\text { Adenosine }\left(+1 \frac{1}{2} \mathrm{H}_{2} \mathrm{O}\right)\end{array}$ & $\begin{array}{r}20 \\
110 \\
110 \\
20\end{array}$ & $\begin{array}{l}A \\
A \\
A \\
A\end{array}$ & $\begin{array}{l}0.002 \\
0.005 \\
0.005\end{array}$ & $\begin{array}{c}9 \cdot 31 \ddagger \ddagger( \pm 0.07) \\
\text { III } \\
-\end{array}$ & $\begin{array}{l}\frac{\ddagger}{4} \\
4 \cdot 22( \pm 0.02) \\
3.52 \Phi \uparrow( \pm 0.04)\end{array}$ \\
\hline
\end{tabular}

$* 1 \cdot 3$ is from the $-\mathrm{SO}_{3} \mathrm{H}$ group (see text).

$\dagger$ This and other upper limits for basic constants were obtained in the strongest solutions which could be made (often supersaturated).

\$ The 4-hydroxyl group.

$\S$ No other $\mathrm{pK}_{a}$ above 5; in the titrations involving metals (Table 2) no pH value below 6.5 was encountered and hence the lower $\mathrm{pK}_{a}$ values do not enter into the calculations.

|| Michaelis, Schubert \& Smythe (1936) obtained 9.8 (and $-0 \cdot 2$ for the basic group) spectrometrically.

T Ogston (1936) obtained 8.7 $\left(\mathrm{H}_{2}\right.$ electrode, $\left.25^{\circ}\right)$ for both substances.

** Approximately.

†† Ogston (1935) obtained 6.0 and $7 \cdot 7$ for xanthine $\left(\mathrm{H}_{2}\right.$ electrode, $\left.18^{\circ}\right)$.

拉 Levene \& Simms (1925) obtained $9 \cdot 16$ (and $1 \cdot 6$ for the basic group). For guanine, Taylor (1948) obtained $9 \cdot 2$ (12.3

for the acidic glyoxaline group and 3.3 for the basic group).

$\S \S 5 \cdot 40$ and 5.54 (Bernouilli \& Loebenstein, 1940).

IIII Taylor (1948) obtained $9 \cdot 80$ (and $4 \cdot 15$ for the basic group), $\mathrm{H}_{2}$ electrode.

Tी Ogston (1936) obtained 3.6; Levene \& Simms (1925), 3.45.

the titration. Thus this $1: 1$ complex must be able to compete strongly with the free metallic cations for the unbound complex-forming species. This mechanism will be referred to as 'simultaneous addition'. When it is operating, equations (i) and (ii) no longer give consistent results, and their place must be taken by equation (v). Conversely, equation (v) does not give consistent results in the usual case where very little of the $1: 2$ complex is formed below $\bar{n}=\mathbf{0} \cdot 8$. Intermediate behaviour was sometimes encountered; even the best example of rapid consecutive addition (4-hydroxypteridine + copper, curve $B$, Fig. 1) shows a tendency to combine according to equation (i) at the very beginning of the titration, but it then approximates to equation (v) and adheres to it (within experimental error) until the end of the titration.

Equation (iii) for $\log K_{s}$ is valid regardless of the type of addition taking place, because it is used only when $\bar{n}=1 \cdot 00$ : at this value of $\bar{n}$, all formation curves pass through the same point (see Fig. 1).

\section{DISCUSSION}

\section{Quinolines}

8-Hydroxyquinoline (I; oxine) proved to have such a high avidity for metals that it was possible to add an equivalent of hydrochloric acid (three equiva- 
lents for $\mathrm{Cu}^{2+}$ and $\mathrm{Fe}^{3+}$ ) before commencing the titration with alkali and thus obtain a series of consistent values for $\log K^{\prime}$. When this addition of acid was omitted, precipitation occurred at the beginning of the titrations, which had therefore to be discarded (the $\mathrm{Mg}^{2+}$ complex was more soluble, however). No conditions could be found to obtain any direct values for $\mathrm{Zn}^{2+}$ because of solubility difficulties. Values of $\log K^{\prime}$ and $\log K^{\prime \prime}$ for the $1: 1$ and $1: 2$ complexes of ferric ion with oxine were found to be 12.35 and 11.3 respectively. The values for the other metals are reported in Table 2.

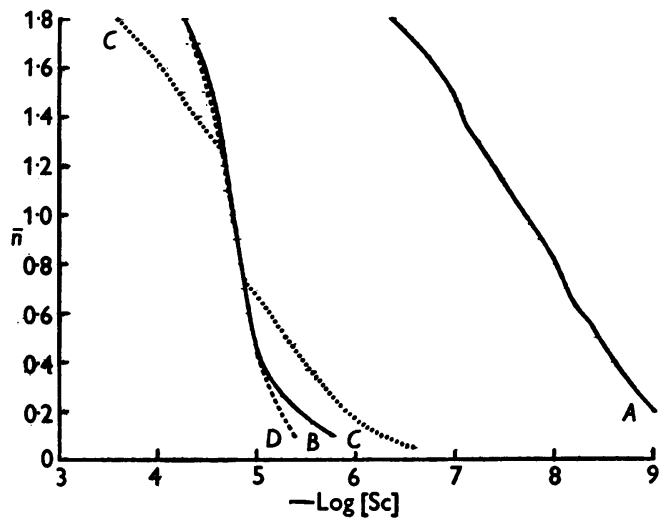

Fig. 1. Formation curves for complexes. $A$, glycine $(0.01 \mathrm{M})$ and $\mathrm{Cu}^{2+}(0.005 \mathrm{M}) ; B$, 4-hydroxypteridine $(0.01 \mathrm{M})$ and $\mathrm{Cu}^{2+}(0.005 \mathrm{M}) ; C$, theoretical curve for $B$, assuming stepwise addition. Log $K^{\prime}$ has been taken as about 1 unit larger than $\log K^{\prime \prime}$ to give normal interaction at $\bar{n}=1$ (in the absence of this interaction, the upper and lower limbs of this curve would be horizontal at $\bar{n}=1$, and would not touch one another); $D$, theoretical curve for $B$, assuming simultaneous addition.

Because all the $\log K^{\prime}$ values of 8-hydroxyquinoline are so close to those of its sulphonic acid, it is likely that the $\log K_{s}$ values of the two substances will also be nearly the same. This hypothesis is strongly supported by some titrations of oxine in the presence of metallic ions carried out in aqueous dioxan, a solvent which gives high values because of its low dielectric constant (e.g. $\log K^{\prime}$ for $\mathrm{Cu}^{2+}$ is 15.0), but which permits the whole titration to be carried out without precipitation (Johnston \& Freiser, 1952; Maley \& Mellor, 1949). These titrations in dioxan show that the frequently observed (approximate) relationship between $\log K^{\prime}$ and $\log K_{s} \quad$ (namely $\log K_{s}=2 \log K^{\prime}-1$ ) holds for oxine. If this relationship is applied to $\log K^{\prime}$ in Table 2, values of $\log K_{s}$ for 8-hydroxyquinoline are obtained which correspond fairly closely to those of its sulphonic acid.

No precipitation occurred during the titrations of 8-hydroxyquinoline-5-sulphonic acid and the curves were clearly seen to be of type $A$ (Fig. 1), that is to say, similar to those given by the amino-acids. Apart from the values in Table 2, the following values were obtained for $\mathrm{Fe}^{3+}\left(\log K^{\prime}=12\right.$; $\log K^{\prime \prime}=11 \cdot 2 ; \log K^{\prime \prime \prime}=9 \cdot 4$; hence $\left.\log K_{s}=36\right)$ and $\mathrm{Ca}^{2+}\left(\log K^{\prime}=3.5 ; \log K_{\mathrm{s}}=5 \cdot 8\right)$. Because of the great avidity of this substance for $\mathrm{Cu}^{2+}$ and $\mathrm{Fe}^{3+}$, mixtures with these cations had to be back-titrated with $\mathrm{N}$-hydrochloric acid to obtain $\log K^{\prime}$, because merely mixing the reagents (i.e. without any addition of alkali) produced values of $\bar{n}$ above $1 \cdot 0$.

It is seen from Table 2 that the stability constants for 8-hydroxyquinoline and its sulphonic acid are greater than any that have yet been encountered in this series of papers, except those of cysteine (Albert, 1952). These quinolines, like the aminoacids, show the usual relative avidities for metals (Albert, 1950 $a$, 1952), namely,

$$
\mathrm{Cu}^{2+}>\mathrm{Ni}^{2+}>\mathrm{Co}^{2+}>\mathrm{Fe}^{2+}>\mathrm{Mn}^{2+}>\mathrm{Mg}^{2+} \text {. }
$$

Mellor \& Maley (1948), who discovered this series, placed $\mathrm{Zn}^{2+}$ near $\mathrm{Co}^{2+}$, and $\mathrm{Cd}^{2+}$ near $\mathrm{Fe}^{2+}$. Zinc and cadmium, however, belong to an independent series and hence their positions among the above transitional elements is likely to vary a little (Irving \& Williams, 1948; Williams, 1950).

\section{Pteridines}

4-Hydroxypteridine (II), in spite of its structural similarity to 8-hydroxyquinoline, has a far lower affinity for metallic ions (see Table 2); even compared with glycine its $\log K$ values are low. Nevertheless, the low value of the acidic $\mathrm{pK}_{a}$ of 4-hydroxypteridine ensures that it is almost entirely in the form of the complex-forming species (the anion) at the physiological $\mathrm{pH}$ of $7 \cdot 3$, a property which would enable it to compete successfully with the common amino-acids in the presence of an equivalent of metallic ions: in fact it would prevail over glycine, proline and many other common amino-acids for $\mathrm{Fe}^{2+}, \mathrm{Ni}^{2+}, \mathrm{Co}^{2+}, \mathrm{Cd}^{2+}$ and $\mathrm{Mn}^{2+}$ (Albert, 1950b). This information was derived from a comparison of $\bar{n}$ values at $\mathrm{pH} 7 \cdot 3$. However, under conditions where the proportion of complex-forming agents to metal is relatively high, it is more correct to compare the $K_{s}$ values directly. When this is done, the position of 4-hydroxypteridine becomes less favourable, as can be seen from Table 2. These two different aspects of comparative avidity are referred to below, under pteroylglutamic acid and guanosine.

4-Hydroxypteridine shows two peculiarities. First, the curve for $\mathrm{Cu}^{2+}$ is as shown in Fig. $\mathrm{l}(B)$ and hence almost simultaneous addition is taking place (this seems also to be the case with $\mathrm{Fe}^{2+}$ and $\mathrm{Mn}^{2+}$, but precipitation prevents inspection of the entire curves). The same results were obtained with copper sulphate as with copper chloride, but copper 
nitrate precipitated a $\mathrm{NO}_{3}^{-}$-containing complex (likewise zinc sulphate precipitated an anioncontaining complex at an earlier stage in the titration than zinc chloride). Secondly, the avidity for $\mathrm{Fe}^{2+}$, relative to that for $\mathrm{Cu}^{2+}, \mathrm{Ni}^{2+}$ and $\mathrm{Co}^{2+}$, is higher than is usually encountered among complexforming substances (Mellor \& Maley, 1948; Irving \& Williams, 1948). The cobalt complex, unlike those of the amino-acids (particularly histidine), did not show any appreciable tendency to absorb oxygen.

4-Hydroxy-6:7-dimethylpteridine (Albert, Brown \& Cheeseman, 1951) gave almost exactly the same curves and constants as 4-hydroxypteridine. 2:4Dihydroxypteridine gave similar curves (there was no doubt that the $\mathrm{Fe}^{2+}$ curve was like B) but somewhat lower constants (Table 2).

Table 2. Stability constants of complexes with metallic cations $\left(\right.$ at $\left.20^{\circ}\right)$

\begin{tabular}{|c|c|c|c|c|c|c|c|c|}
\hline \multirow[b]{2}{*}{ Substance } & \multicolumn{2}{|c|}{$\mathrm{Cu}^{2+}$} & \multicolumn{2}{|c|}{$\mathrm{Ni}^{2+}$} & \multicolumn{2}{|c|}{$\mathrm{Zn}^{2+}$} & \multicolumn{2}{|c|}{$\mathrm{Co}^{2+}$} \\
\hline & log $K^{\prime}$ & $\log K_{8}$ & $\overparen{\log K^{\prime}}$ & $\log K_{8}$ & $\log K^{\prime}$ & $\log K_{8}$ & $\log K^{\prime}$ & $\log K_{8}$ \\
\hline $\begin{array}{l}\text { Glycine (for comparison) } \\
\text { 8-Hydroxyquinoline }\end{array}$ & $\begin{array}{r}8 \cdot 5 \\
12 \cdot 2\end{array}$ & $\underline{15}^{*}{ }^{*} \dagger$ & $\begin{array}{l}6 \cdot 1 \\
9 \cdot 9\end{array}$ & $\underline{11 \cdot 0 *}+$ & $5 \cdot 2$ & $\underline{9 \cdot 3 *}^{-}$ & $\begin{array}{l}5 \cdot 1 \\
9 \cdot 1\end{array}$ & $\stackrel{8 \cdot 9 * \dagger}{-}$ \\
\hline $\begin{array}{l}\text { 8-Hydroxy quinoline-5-sulphonic } \\
\text { acid }\end{array}$ & $12 \cdot 5$ & $23 \cdot 1 * \dagger$ & $10 \cdot 0$ & $18 \cdot 1^{*} \dagger$ & $8 \cdot 4$ & $15 \cdot 1 * \dagger$ & $\mathbf{9} \cdot \mathbf{2}$ & $16 \cdot 8^{*} \dagger$ \\
\hline \multicolumn{9}{|l|}{ Pteridine } \\
\hline 4-Hydroxy- & $\|$ & $9 \cdot 5 * \pi$ & $4 \cdot 4$ & $\left\{\begin{array}{l}7 \cdot 8^{*} \\
8 \cdot 1 \dagger\end{array}\right.$ & $3 \cdot 3$ & $\S$ & $3 \cdot 8$ & $6 \cdot 6^{*} \dagger$ \\
\hline $\begin{array}{l}\text { 2:4-Dihydroxy- } \\
\text { 6-Anilinomethyl-4-hydroxy- } \\
\text { 6-Anilinomethyl-4-hydroxy-p- }\end{array}$ & ㅍ & $\begin{array}{r}8 \cdot 3 \rrbracket \\
\S \\
\S\end{array}$ & $\begin{array}{l}3 \cdot 7 \\
\S \\
4 \cdot 0\end{array}$ & $\frac{6 \cdot 5^{*}}{\S}$ & $\bar{\S}$ & $\bar{\S}$ & $\begin{array}{l}3 \cdot 2 \\
3 \cdot 5 \\
3 \cdot 7\end{array}$ & $\begin{array}{l}\S \\
6^{8} \cdot 5^{*}\end{array}$ \\
\hline $\begin{array}{l}\text { sulphonate, sodium salt } \\
\text { Pteroylglutamic acid }\end{array}$ & $\S$ & $7 \cdot 8^{*}$ & 8 & $9 \cdot 0^{*}$ & 8 & $7 \cdot 5^{*}$ & $\S$ & $8 \cdot 1^{*}$ \\
\hline Riboflavin & $\|$ & $\left\{\begin{array}{l}13 \cdot 1^{*} \\
12.99\end{array}\right.$ & $4 \cdot 1$ & $\S$ & $5 \cdot 6$ & $\S$ & $\mathbf{3 . 9}$ & $\S$ \\
\hline \multirow[t]{2}{*}{$\begin{array}{l}\text { Inosine } \\
\text { Hypoxanthine } \\
\text { Guanosine } \\
\text { Xanthosine }\end{array}$} & $\begin{array}{l}5 \ddagger \\
6 \cdot 2 \\
6 \ddagger \\
3 \cdot 4\end{array}$ & $\begin{array}{l}\S \\
\S \\
\S \\
\S\end{array}$ & $\begin{array}{l}3 \cdot 3 \\
4 \cdot 7 \\
3 \cdot 8 \\
3 \cdot 0\end{array}$ & $\begin{array}{l}\S \\
\S \\
\S \\
\S\end{array}$ & $\begin{array}{l}\S \\
\S \\
4 \cdot 6 \\
2 \cdot 4\end{array}$ & $\overline{\bar{z}}$ & $\begin{array}{l}2 \cdot 6 \\
3 \cdot 8 \\
3 \cdot 2 \\
2 \cdot 8\end{array}$ & $\begin{array}{l}\S \\
\S \\
\S \\
\S\end{array}$ \\
\hline & \multicolumn{2}{|c|}{$\mathrm{Cd}^{2+}$} & \multicolumn{2}{|c|}{$\mathrm{Fe}^{2+}$} & \multicolumn{2}{|c|}{$\mathbf{M n}^{2+}$} & \multicolumn{2}{|c|}{$\mathrm{Mg}^{\mathbf{2 +}}$} \\
\hline Substance & $\log K^{\prime}$ & $\log K_{s}$ & $\log K^{\prime}$ & $\log K_{s}$ & $\log K^{\prime}$ & $\log K_{s}$ & $\log K^{\prime}$ & $\log K_{8}$ \\
\hline $\begin{array}{l}\text { Glycine (for comparison) } \\
\text { 8-Hydroxyquinoline } \\
\text { 8-Hydroxyquinoline-5-sulphonic } \\
\text { acid }\end{array}$ & $\begin{array}{l}4 \cdot 5 \\
7 \cdot 2 \\
7 \cdot 6\end{array}$ & $\frac{8 \cdot 1^{* \dagger}}{13 \cdot 5^{*} \dagger}$ & $\begin{array}{l}4 \cdot 3 \\
8 \cdot 0 \\
8 \cdot 4\end{array}$ & $\frac{7 \cdot 8^{*} \dagger}{15 \cdot 1^{*} \dagger}$ & $\begin{array}{l}3 \cdot 2 \\
6 \cdot 8 \\
6 \cdot 6\end{array}$ & $\frac{5 \cdot 5^{*} \dagger}{11 \cdot 5^{*}}$ & $\begin{array}{l}2 \ddagger \\
4 \cdot 5 \\
4 \cdot 8\end{array}$ & $\frac{4 \ddagger}{8 \cdot 5^{*} \dagger}$ \\
\hline $\begin{array}{l}\text { Pteridine } \\
\text { 4-Hydroxy- }\end{array}$ & 3.4 & $\S$ & 3.4 $\ddagger$ & $\left\{\begin{array}{l}5 \cdot 9^{*} \\
6 \cdot 29\end{array}\right.$ & $2 \cdot 4 \ddagger$ & 4.5T & $<1$ & - \\
\hline $\begin{array}{l}\text { 2:4-Dihydroxy- } \\
\text { 6-Anilinomethyl-4-hydroxy- } \\
\text { 6-Anilinomethyl-4-hydroxy-p- } \\
\text { sulphonate, sodium salt }\end{array}$ & $\bar{\S}$ & $\bar{z}$ & $\stackrel{2 \cdot 9 \ddagger}{\S}$ & $=$ & $\overline{-}$ & $\bar{z}$ & $\bar{z}$ & $\bar{z}$ \\
\hline $\begin{array}{l}\text { Pteroylglutamic acid } \\
\text { Riboflavin } \\
\text { Inosine } \\
\text { Hypoxanthine } \\
\text { Guanosine } \\
\text { Xanthosine }\end{array}$ & $\begin{array}{l}4 \cdot 0 \\
4 \cdot 7 \\
- \\
4 \cdot 0 \\
-\end{array}$ & $\frac{6 \cdot 7^{*}}{\frac{\S}{-}}$ & $\begin{array}{l}\S \\
7 \cdot 1 \\
3 \ddagger \\
3 \cdot 9 \\
4 \cdot 3 \\
<2\end{array}$ & $\begin{array}{l}7.9 * \\
\S \\
\S \\
\S \\
\S \\
-\end{array}$ & $\begin{array}{l}\S \\
3 \cdot 4 \\
2 \cdot 4 \\
3 \cdot 0 \\
-\end{array}$ & $\frac{6 \ddagger}{\S}$ & $\begin{array}{l}\bar{z} \\
\bar{E} \\
\bar{z}\end{array}$ & $\begin{array}{l}\text { ** } \\
\text { 二 } \\
= \\
=\end{array}$ \\
\hline $\begin{array}{l}\text { * Calculated from value of log } \\
\text { † By addition of } \log K^{\prime} \text { and lo } \\
\text { † Approximately. } \\
\S \text { Poor solubility of complex p } \\
\text { \| No direct evaluation possible } \\
\text { I From equation (v). } \\
\text { ** No depression of pH in pre }\end{array}$ & at $n$ & 00 , by & on (i & -1 & & & & \\
\hline
\end{tabular}

Table 3. Depression of the $\mathrm{pH}$ of solutions of pteridines ( $0.001 \mathrm{~m}$ ) in water (oxygen free) on the addition of metallic salts $(0 \cdot 0005 \mathrm{M} ; \mathrm{pH} 5 \cdot 6-6 \cdot 4)$

Pteridine

4:6-Dihydroxy- (pH 5.01)

2-Amino-4:6-dihydroxy- (xanthopterin) (pH 5י49)

$\begin{array}{ccccccc}\mathrm{CuCl}_{2} & \mathrm{Ni}\left(\mathrm{NO}_{3}\right)_{2} & \mathrm{ZnCl}_{2} & \mathrm{Co}\left(\mathrm{NO}_{3}\right)_{2} & \mathrm{CdSO}_{4} & \mathrm{FeSO}_{4} & \mathrm{MnSO}_{4} \\ \mathbf{1 . 2 3} & 0.88 & 0.46 & 0.42 & - & 0.43 & 0 \\ 1.90 & \mathbf{1 . 4 6} & \mathbf{1 . 0 0} & \mathbf{1 . 0 9} & \mathbf{0 . 9 0} & \mathbf{0 . 5 7} & \mathbf{0 . 1 3}\end{array}$


4:7-Dihydroxypteridine (Albert \& Brown, 1953) differs from this isomeride in that the ionization of the non-chelating hydroxyl group is complete before the 4-hydroxy group has ionized to any extent (see Table 1). Because of the insolubility of its complexes, the only value obtainable was $\log K^{\prime}$ for $\mathrm{Co}^{2+}(5 \cdot 7)$. This value is considerably in excess of those given by the pteridines already discussed, but follows the rule that, in any series, weakening of acidic properties (or strengthening of basic properties) increases the avidity for metals. In the present case, the 4-hydroxyl group is weakened by the usual coulombic effect due to the nearness of another anion (that of the 7-hydroxyl group). From this reasoning, high avidity was expected also from 4:6-dihydroxypteridine and xanthopterin (2-amino4:6-dihydroxypteridine).

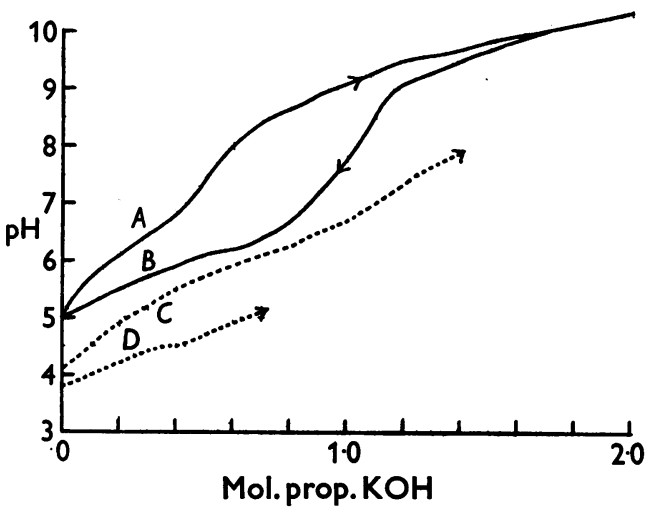

Fig. 2. Titration of 4:6-dihydroxypteridine $(0.001 \mathrm{~m}) . A$, Titration with $\mathrm{KOH}(0 \cdot 1 \mathrm{M}) ; B$, back-titration of $A$ with $\mathrm{HCl}(0 \cdot 1 \mathrm{M})$. The noncoincidence of $A$ and $B$ shows that a slow tautomerization is taking place; $C$, as $A$, but $\mathrm{Ni}^{2+}$ is present $(0.0005 \mathrm{M}) ; D$, as $A$, but $\mathrm{Cu}^{2+}$ is present $(0.0005 \mathrm{M})$.

As it happens, pteridines bearing a hydroxyl group in the 6-position undergo a slow tautomerization upon titration (Albert, Brown \& Cheeseman, 1952a). 4:6-Dihydroxypteridine gives the pair of curves $A$ and $B$ (Fig. 2) upon titration with alkali and acid respectively, the curve $A$ tending to approach $B$ with the lapse of time. Xanthopterin behaves similarly. It is evident that bivalent cations (as exemplified by nickel and copper in curves $C$ and $D$ respectively) cause a large displacement of curve $A$ to more acid $\mathrm{pH}$ values. Unfortunately, stability constants cannot be calculated from this liberation of hydrogen ions unless the solubility of the complex permits titration to proceed well into the region of the second equivalent of alkali (this was possible in the case of $\mathrm{Ni}^{2+}$ only, which gave $\log K^{\prime}=5 \cdot 5$ ). This limitation arises from the fact that the lower half of curve $A$ corresponds to no $\mathrm{pK}_{a}$, and owes its horizontal component mainly to the presence of small amounts of mono-anion, for which the lower half of curve $B$ provides the true $\mathrm{pK}_{a}$ (trial calculations showed that the amount of mono-anion was varying unpredictably throughout the titrations involving metals). For xanthopterin, which gave even more insoluble complexes, no constant could be recorded. However, the large liberation of hydrogen ions, on bringing together this substance and metallic cations, makes it clear that the avidity for metals was considerably greater than that of 4:6-dihydroxypteridine (see Table 3). This increase in avidity, due to the 2-amino group, is referred to again later, under pteroylglutamic acid.

The inhibition of the oxidation of a colourless precursor of melanin by xanthopterin (Isaka, 1952) may be due to the abstraction of $\mathrm{Cu}^{2+}$ (or another heavy cation) by the pteridine at this step which normally occurs in the dark and without enzymes. Many other 4-hydroxypteridines inhibit the initial oxidation of dihydroxyphenylalanine in melanogenesis (Polonovski, Gonnard \& Baril, 1951).

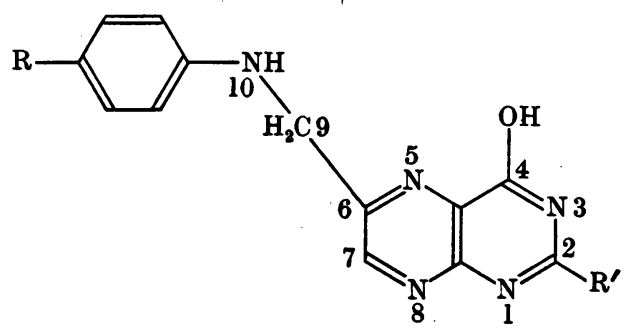

(VIII)

(a) $\mathbf{R}$ and $\mathbf{R}^{\prime}=-\mathrm{H}$.

(b) $\mathrm{R}=-\mathrm{SO}_{8} \mathrm{Na}, \mathrm{R}^{\prime}=-\mathrm{H}$.

(c) $\mathrm{R}=-\mathrm{CONH}-\mathrm{CH}(\mathrm{COOH}) \cdot \mathrm{CH}_{2} \cdot \mathrm{CH}_{2} \cdot(\mathrm{COOH})$, $\mathbf{R}^{\prime}=-\mathrm{NH}_{\mathbf{8}}$ (pteroylglutamio acid).

6-Anilinomethyl-4-hydroxypteridine (VIII, a) was chosen as a simple model for pteroylglutamic acid (folic acid) (VIII, $c$ ). It was thought that these substances might use simultaneously both $\mathrm{N}_{(5)}$ and $\mathrm{N}_{(10)}$ in binding metals, the distances being suitable. Such terdentate complexes would give high values of $\log K^{\prime}$. Unfortunately, the complexes of (VIII, $a$ ) are only sparingly soluble and only in the case of $\mathrm{Co}^{2+}$ could a significant portion of the titration curve be inspected. To confer greater solubility, a sulphonic group was introduced, giving (VIII, $b$ ), which revealed more of the chelation process before precipitation of the complexes occurred. Neither in the case of (VIII, $a$ ) nor (VIII, $b$ ) did the magnitudes of the constants suggest any departure from the mode of chelation of 4-hydroxypteridine. It is regrettable that the $\mathrm{Fe}^{2+}$ complexes of (VIII, a and $b$ ) were so insoluble, because this metal (which has a greater tendency to hexacovalence than any of the others studied) could most readily employ the extra co-ordination latent in (VIII) and thus achieve terdentate combination, as opposed to 
the more common bidentate combination shown in (VII).

Pteroylglutamic acid (VIII, c) forms highly insoluble salts with the heavy metals, but only in the lower $\mathrm{pH}$ range. This effect would seem to be due to ordinary salt formation between the carboxylic acid groups and the metallic cations. Above pH 7, where the ionization of the 4-hydroxyl group becomes substantial, these precipitates dissolve and the colours characteristic of 4-hydroxypteridine complexes appear, for example the yellow precipitate of ferrous pteroylglutamate turns into a bloodred solution as the metal is transferred from a carboxyl group to the pteridine nucleus, to give complexes of the types (VI) and (VII). Hence it was found that the best way to carry out these titrations was to dissolve the pteroylglutamic acid $(0.002 \mathrm{M})$ with the aid of from $2 \cdot 0$ to $2 \cdot 4$ equivalents of potassium hydroxide, then to add the metallic salt and to proceed with the alkaline titration. This method revealed a good deal of the titration curves (from $\bar{n}=0.7$ to $1 \cdot 8$ ), including the important point where $\bar{n}=1 \cdot 0$. The results, given in Table 2 , show that the constants are, in almost every case, higher than those of any pteridine which it has been possible to measure so far. This heightened avidity is most likely due to the presence of the 2-amino group (as in the pair xanthopterin and 4:6-dihydroxypteridine discussed above). The high constants of the pteroylglutamic acid cobalt and iron complexes, coupled with the high degree of ionization $\left(\mathrm{pK}_{a}=8 \cdot 3\right)$ of the hydroxyl group in pteroylglutamic acid combine to make it a powerful competitor for these two metals, even in the presence of amino-acids. The MellorMaley sequence (see p. 649) is not strictly adhered to, the principal change being a strong depression of the constant for $\mathrm{Cu}^{2+}$ (compare the $\log K_{s}$ values for pteroylglutamic acid with those for 4-hydroxypteridine, Table 2). The cause of this depression may well be a certain amount of steric hindrance in the $1: 2$ complex between the side chain and the oxygen in the 4-position of the other pteridine molecule, an effect that will be easily visualized from an inspection of (VII). The only ion used in this work that would be affected by such a hindrence, is $\mathrm{Cu}^{2+}$, because it alone forms exclusively planar complexes. If this hypothesis is correct, $\log K^{\prime}$ should be normal. This cannot be verified because of insolubility, but the first half of the titration curve of 6-anilinomethyl-4-hydroxypteridine appeared to be normal. Except for cadmium, the titration curves of the other metals with pteroylglutamic acid, as far as they can be followed in either direction, seem to have a fairly steep slope (i.e. a tendency towards simultaneous addition is present): No evidence for terdentate combination was found for any metal. That the benzoylglutamic acid portion does not take part in complex formation, at or above $\mathrm{pH} 7$, follows from the investigation of L-benzoylglutamic acid in Part 2 (Albert, 1952). Pteroylglutamic acid did not appear to form any complex with $\mathrm{Fe}^{3+}$. The dimethyl ester (in which the $\alpha$-and $\gamma$-carboxylic groups of the glutamic acid portion are esterified) proved to be too insoluble to titrate.

The following pteridines, which are too sparingly soluble to titrate, showed evidence of chelation by giving a red colour with ferrous sulphate in borate buffer at pH 8.0: 4:6:7-trihydroxy-, 2-amino-4hydroxy-and 2-amino-4:7-dihydroxy-pteridine (the last named is isoxanthopterin). This colour reaction is also given by all the pteridines of Table 2 . 2-Amino-4:6:7-trihydroxypteridine (leucopterin) was too insoluble at $\mathrm{pH} 8$ to be tested. 2-, 6- and 7 Hydroxypteridines showed no evidence of combining with metallic ions. When 4-aminopteridine hydrochloride was titrated in the presence of $\mathrm{Cu}^{2+}$, a weak tendency $\left(\log K^{\prime}=2 \cdot 5\right)$ to complex formation was revealed. Complexes of this kind are given by nearly all amines (cf. ammonia $+\mathrm{Cu}^{2+}$, $\left.\log K^{\prime}=4 \cdot 0\right)$.

\section{Riboflavin}

Although riboflavin has been studied extensively for the last 20 years, its considerable metal-binding powers have only recently been described (Albert, $1950 \mathrm{c}$ ). This is not surprising, because the formula is not usually written as (III), but as a tautomer which does not show the close analogy with 8hydroxyquinoline. Titrations gave the results reported in Table 2. Only $\mathrm{Cu}^{2+}$ showed more consistent results when calculated from (v) than from (i), and hence it may be supposed that this metal allows simultaneous addition (see p. 648). This evidence of lack of steric hindrance (contrast with pteroylglutamic acid, above) may spring from the non-planarity of the isoalloxazine nucleus, which is not conjugated throughout.

The most remarkable feature of the $\log K^{\prime}$ values for riboflavin is the high value obtained for the $\mathrm{Fe}^{2+}$ complex. Apparently, the avidity of riboflavin for ferrous ions is greater than for any other metallic ion studied. Unfortunately the titration of $\mathrm{Fe}^{2+}$ could be followed only as far as $\bar{n}=0 \cdot 30$ before pre. cipitation of the complex occurred, so that nothing is known about the shape of the curve except that there was no evidence of simultaneous addition. Riboflavin must be added to the very short list of known substances (e.g. o-phenanthroline; 2:2'dipyridyl) which promote $\mathrm{Fe}^{2+}$ out of its natural position in the avidity sequence of ions (see p. 649; also under guanosine, below).

It is interesting to compare the $\log K^{\prime}$ values of riboflavin, glycine and 8-hydroxyquinoline because all three substances have the same acid ionization constant $\left(\mathrm{pK}_{a}=9.9\right)$, and hence their relative avidities under all circumstances are proportional to 
their $K^{\prime}$ values. It will be seen that riboflavin has more avidity than glycine for several metals, particularly for $\mathrm{Fe}^{2+}$ where the avidity is nearly as great as that of 8-hydroxyquinoline. Riboflavin did not appear to combine with $\mathrm{Fe}^{3+}$; moreover, it did not appear to be reduced by $\mathrm{Fe}^{2+}$.

These results open up the possibility that the activity of some riboflavin-containing enzymes may be associated with metallic ions. It is hoped that those who work with the yellow enzymes will report any inhibitions obtained with complex-forming agents (e.g. 8-hydroxyquinoline). In this respect, xanthine oxidase would be interesting, because its substrate (xanthine), its product (uric acid), its coenzyme (a riboflavin derivative) and 2-amino-6formyl-4-hydroxypteridine which inhibits it very strongly (Lowry, Bessey \& Crawford, 1949) can all form complexes, like (VI), with a bivalent cation. It is interesting that riboflavin has already been found associated with iron, namely in a protein (conalbumin) which is found in the avian blood stream and in egg-white (Bain \& Deutsch, 1948).

\section{Purines}

It is surprising that the metal-binding properties of purines having a free hydroxyl group in the 6position have remained largely unsuspected. Their avidity (see Table 2) is comparable to that of the pteridines (other than pteroylglutamic acid). A tendency for the value for $\mathrm{Fe}^{2+}$ to exceed that of $\mathrm{Co}^{2+}$ (and even $\mathrm{Ni}^{2+}$ ), a feature reminiscent of riboflavin, is seen most strongly in guanosine. All the purine complexes seemed to be formed normally, i.e. by stepwise (as opposed to simultaneous) addition. The choice of the right constants for the calculations presented no difficulty in the case of inosine and guanosine, which have only one acidic group. In the case of xanthosine and hypoxanthine, which have a second, weakly acidic, group of $\mathrm{pK}_{a}>11$, the more consistent results were obtained by assuming that the $\mathrm{pK}_{a}$ constants 5.7 and 8.9 (respectively) belonged to the complex-forming 6-hydroxyl group. As in the pteridines, an amino group in the 2-position raises the constants, whereas a similarly placed hydroxyl group lowers them.

The figures obtained for guanosine are particularly interesting because this purine occurs in nucleic acids. It is seen to have the same avidity for $\mathrm{Fe}^{2+}$ as glycine has (as measured by $\log K^{\prime}$ ); indeed its $\mathrm{pK}_{a}$ of $\mathbf{9 \cdot 3}$ (as against $\mathbf{9} \cdot 9$ for glycine) would make it slightly the more effective competitor under certain circumstances (as discussed above for 4hydroxypteridine). Some titrations were also performed on uric acid, for which the order of avidity was plainly $\mathrm{Fe}^{2+}>\mathrm{Cu}^{2+}>\mathrm{Co}^{2+}$, as shown by depression of $\mathrm{pH}$. Because the titration was carried out in supersaturated solutions, and because of the difficulty of assigning $\mathrm{pK}_{a}$ values to the correct acidic groups, no calculations were attempted for these uric acid complexes.

Adenosine (which has no acidic group) forms no detectable complex with $\mathrm{Cu}^{2+}, \mathrm{Co}^{2+}$ or other metal, the same pH values being obtained on titration in the presence or absence of the metallic cation. Adenine gave a weak complex with copper $\left(\log K^{\prime}=2 \cdot 5\right)$ which is more likely to be of the type given by many other amines with this metal, rather than one involving the acidic group in the 9-position. Whether adenine $(0.005 \mathrm{M})$ was titrated in the absence or presence of $\mathrm{Co}^{2+}(0.0025 \mathrm{M})$, the same $\mathrm{pH}$ values were obtained, thus indicating that any complex formed with cobalt can have little stability. Liquier-Milward (1951) has isolated a $1: 1$ cobaltadenine complex from aqueous solution, but the above titration shows that the avidity of the adenine for $\mathrm{Co}^{2+}$ is very low.

\section{Colours of complexes}

The natural amino-acids form blue complexes with $\mathrm{Cu}^{2+}$, green with $\mathrm{Ni}^{2+}$ and $\mathrm{Fe}^{2+}$ and pink with $\mathrm{Co}^{2+}$. The only exceptions seem to be cysteine (red with $\mathrm{Ni}^{2+}, \mathrm{Fe}^{2+}$ and $\mathrm{Co}^{2+}$ ) and histidine (which has both orange and pink $\mathrm{Co}^{2+}$ complexes). The purine complexes are similar in colour to those of the aminoacids. The complexes of riboflavin are yellow. The pteridines (including pteroylglutamic acid) and the 8-hydroxyquinolines form green complexes with $\mathrm{Cu}^{2+}$ and $\mathrm{Ni}^{2+}$, orange with $\mathrm{Co}^{2+}$ and red with $\mathrm{Fe}^{2+}$. The quinolines form dark-green complexes with $\mathrm{Fe}^{3+}$, whereas the other substances mentioned seem not to form complexes with this cation.

\section{SUMMARY}

1. The avidities of natural and synthetic pteridines, of riboflavin and of several natural purines for the ions of heavy metals have been measured and recorded in the form of stability constants. For purposes of comparison, 8-hydroxyquinoline and its sulphonic acid were also investigated.

2. These substances form a related series in so far as they combine with metals through the same arrangement of atoms, namely, a hydroxyl group peri to a ring-nitrogen atom. Two different patterns for the stages of combination were demonstrated.

3. Riboflavin and guanosine showed a heightened affinity for $\mathrm{Fe}^{2+}$, and pteroylglutamic acid showed a lowered affinity for $\mathrm{Cu}^{2+}$ (relative to the usual gradation of affinity for the different metals). Thus this series shows evidence of specificity for particular metallic cations which is entirely lacking among the amino-acids.

4. Some quantitative implications for conditions in the living cell are discussed. 
The author wishes to thank Mr J. N. Phillips for valuable theoretical discussions, Dr D. J. Brown for preparing a number of analogues of pteroylglutamic acid in an en- deavour to find examples with more soluble complexes and Mr E. P. Serjeant who carried out a large number of the titrations.

\title{
REFERENCES
}

Albert, A. (1950a). Biochem. J. 47, 531.

Albert, A. (1950b). Biochem. J. 47, ix.

Albert, A. (1950c). Biochem. J. 47, xxvii.

Albert, A. (1952). Biochem. J. 50, 690.

Albert, A. \& Brown, D. J. (1953). J. chem. Soc. p. 74.

Albert, A., Brown, D. J. \& Cheeseman, G. (1951). J. chem.

Soc. p. 474.

Albert, A., Brown, D. J. \& Cheeseman, G. (1952a). J. chem. Soc. p. 1620.

Albert, A., Brown, D. J. \& Cheeseman, G. (1952b). J.chem. Soc. p. 4219.

Albert, A., Gibson, M. \& Rubbo, S. (1953). Brit. J. exp. Path. 84, 119.

Albert, A., Rubbo, S., Goldacre, R. \& Balfour, B. (1947). Brit. J. exp. Path. 28, 69.

Albert, A. \& Wood, H. C. S. (1952).' J. appl. Chem. 2, 591.

Bain, J. \& Deutsch, H. (1948). J. biol. Chem. 172, 547.

Bernouilli, A. \& Loebenstein, A. (1940). Helv. chim. acta, 23, 245.

Brown, D. J. (1953). J. chem. Soc. (in the Press).

Irving, H. \& Williams, R. (1948). Nature, Lond., 162, 746.

Isaka, S. (1952). Nature, Lond., 169, 74.
Johnston, W. \& Freiser, H. (1952). J. Amer. chem. Soc. 74, 5239.

Levene, P. \& Jacobs, W. (1910). Ber. dtsch. chem. Ges. 43, 3150.

Levene, P. \& Simms, H. (1925). J. biol. Chem. 65, 519.

Liquier-Milward, J. (1951). Nature, Lond., 167, 1068.

Lowry, O. H., Bessey, O. A. \& Crawford, E. J. (1949). J. biol. Chem. 180, 389, 399.

Maley, L. \& Mellor, D. (1949). Aust. J. sci. Res. 2, 92.

Mellor, D. \& Maley, L. (1948). Nature, Lond., 161, 436.

Michaelis, L., Schubert, M. P. \& Smythe, C. V. (1936). J. biol. Chem. 116, 587.

Musajo, L. (1935). Atti Accad. 'Nuovi Lincei', 21, 368.

Ogston, A. (1935). J. chem. Soc. p. 1376.

Ogston, A. (1936). J. chem. Soc. p. 1713.

Polonovski, M., Gonnard, P.\& Baril, A. (1951). Enzymologia 14, 311.

Rubbo, S., Albert, A. \& Gibson, M. (1950). Brit. J. exp. Path. 81, 425 .

Taylor, H. (1948). J. chem. Soc. p. 765.

Williams, R. (1950). Ph.D. thesis, University of Oxford.

\section{Some Observations on the Instability of Adenine Nucleotides in Bird-liver Preparations}

\author{
By ELISABETH I. B. DRESEL* \\ Department of Biochemistry, University of Cambridge
}

(Received 26 November 1952)

In the course of a study of purine metabolism in suspensions of bird liver it was observed that incubation in the presence of 2:4-dinitrophenol (DNP) results in a considerable formation of free purines. It seemed unlikely that these would be of synthetic origin, and an investigation of possible catabolic sources showed that the liberated purines could be accounted for almost entirely by an extensive breakdown of the free adenine nucleotides in the tissue. The nucleic acid content of such preparations remained relatively unaffected. Other inhibitors of oxidative phosphorylation and, furthermore, the addition of magnesium ions gave similar results. Investigations with the soluble and insoluble fractions of the suspensions and with chick-liver slices are also described.

* Present address: Department of Chemical Pathology, University College Hospital Medical School, London, W.C. 1.

\section{MATERIALS AND METHODS}

Chicks. Day-old chicks were obtained from hatcheries and fed on chick mash, which was gradually supplemented with, and finally replaced by, crushed oats and greenstuffs at 8 weeks. Chicks were used from 2-12 weeks old. They were usually allowed to feed until shortly before being killed, but in two experiments (88 and 90) they were starved for $20 \mathrm{hr}$. before death.

Pigeons. Adult pigeons were obtained from dealers and used at once.

Uric acid. Uric acid was determined by the colorimetric method of Brown (1945), modified as described by Dresel \& Moyle (1950).

Pentose. Pentose was determined by the method of Mejbaum (1939) with modifications suggested by Ogur \& Rosen (1950).

Inorganic, 10 min. acid-labile and total phosphates. These were determined by the method of Fiske \& Subbarow (1925), using the micromodifications of Mitchell \& Moyle (1951). 